\title{
Anterior ischemic optic neuropathy associated with metabolic syndrome
}

\author{
Neuropatia óptica isquêmica anterior associada a síndrome metabólica
}

\author{
Natalija Kosanovic-Jakovic ${ }^{1}$ \\ Branislava Ivanovic ${ }^{2}$ \\ Svetislav Milenkovic ${ }^{3}$ \\ Dusica Risovic $^{4}$ \\ Vesna Dimitrijevic-Sreckovic ${ }^{5}$ \\ Aleksandra Radosavljevic ${ }^{6}$ \\ Dijana Risimic $^{7}$ \\ Mirko Resan $^{8}$
}

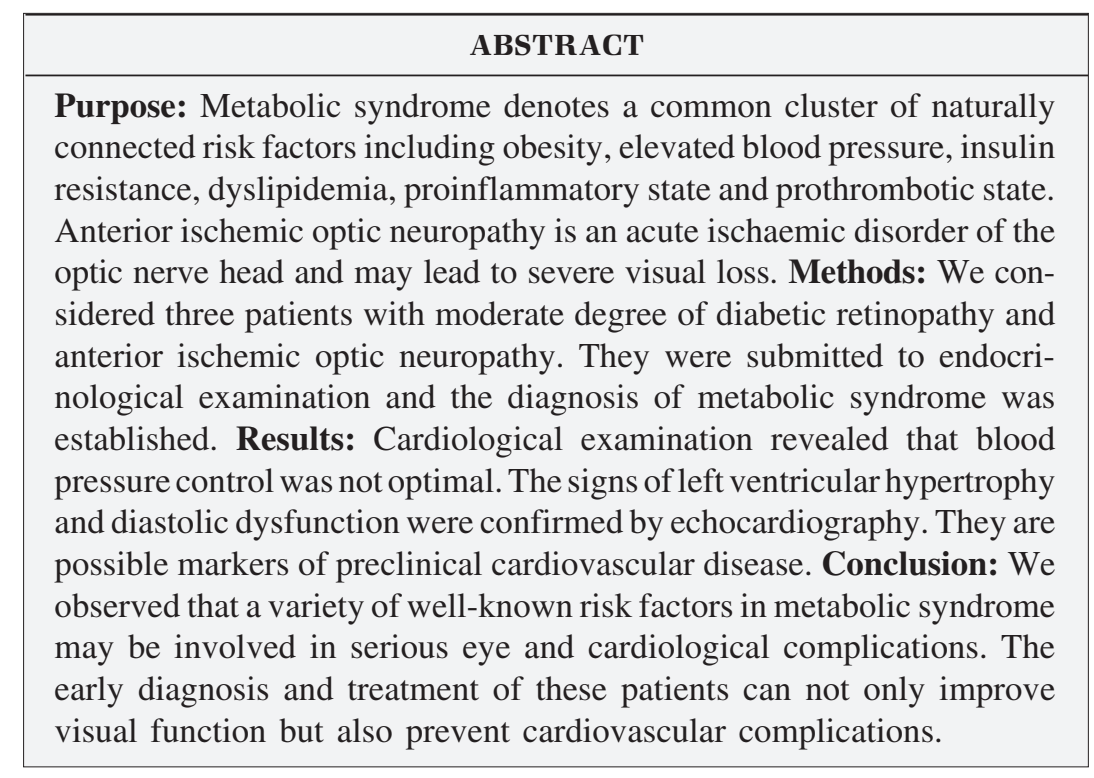

Keywords: Metabolic syndrome X; Optic neuropathy, ischemic; Cardiovascular diseases

\section{INTRODUCTION}

Anterior ischemic optic neuropathy (AION) represents an acute ischemic disorder of the optic nerve and may lead to severe visual loss. Clinically it is classified into two groups: arteritic (A-AION) caused by giant cell arteritis and non-arteritic (NA-AION) ${ }^{(1)}$. The pathogenesis of NAAION is not completely understood. NA-AION is a multifactorial disease. In addition to predisposing anatomic factors, systemic factors play an important role in the pathogenesis of NA-AION ${ }^{(1-2)}$. Systemic risk factors (arterial hypertension, diabetes mellitus, obesity, dyslipidemia etc.) are proved to have an influence on microcirculation and blood flow autoregulation of the optic nerve head ${ }^{(1,3)}$. We consider the connection between metabolic syndrome and NA-AION.

The definition of metabolic syndrome (MS) has been given by the WHO, the American Association of Clinical Endocrinologists (AACE) and the Adult Treatment Panel III report of the National Cholesterol Education Program (ATP III) $^{(4-5)}$. They identify six components of the MS related to cardiovascular disease (CVD): abdominal obesity, atherogenic dyslipidemia, arterial hypertension (HTA), insulin resistance and/or glucose intolerance, proinflammatory state and prothrombotic state. Further diagnostic criteria have been postulated by the International Diabetes Federation (IDF) ${ }^{(6)}$. 
Current concepts of treatment of MS and vascular complications are medically supervised lifestyle changes, treatment of obesity with diet, increased physical activity and medical treatment for diabetes and hypertension ${ }^{(4-5)}$.

\section{METHODS}

We considered three patients with MS and NA-AION. Diagnosis of MS was established by an endocrinologist according to the latest diagnostic criteria (ATP III and IDF). A person has MS if three of the following five conditions are observed:

- body mass index (BMI) $>30 \mathrm{~kg} / \mathrm{m}^{2}$ and waist circumference $\geq 102 \mathrm{~cm}$ in men and $\geq 88 \mathrm{~cm}$ in women.

- Elevated fasting glucose level $\geq 110 \mathrm{mg} / \mathrm{dl}$ ( $(\geq 6.1 \mathrm{mmol} / \mathrm{l})$, elevated hemoglobin A1c $(\mathrm{HbAlc})>6.8 \%$ or if the person has been receiving drug treatment for elevated glucose level.

- High-density lipoprotein cholesterol (HDL) level $<40$ $\mathrm{mg} / \mathrm{dl}(<1.04 \mathrm{mmol} / \mathrm{l})$ in men and $<50 \mathrm{mg} / \mathrm{dl}(<1.30 \mathrm{mmol} / \mathrm{l})$ in women or if the person has been receiving drug treatment for reduced HDL level.

- Triglyceride level $>150 \mathrm{mg} / \mathrm{dl}(>1.70 \mathrm{mmol} / \mathrm{l})$ or if the person has been receiving treatment for elevated level of triglyceride.

- Hypertension (HTA) was determined as blood pressure $\geq 140 / 90 \mathrm{mmHg}$ or if the person has been receiving treatment for hypertension.

- Proinflammatory state was determined by elevated levels of C-reactive protein and fibrinogen.

Standard ophthalmological examination and fluorescein angiography were performed. Cardiological examination included: evaluation of objective state, blood pressure control, electrocardiography (ECG), echocardiography and color Doppler of the carotid arteries. Other diseases were noted as well.

\section{CASE PRESENTATION}

\section{Case 1}

A 43-year-old male was hospitalized at the Medical Retina Department in March 2006 because of deterioration of vision in his left eye. Previous history revealed a deterioration of vision in the right eye five months before, when he was examined by an ophthalmologist and endocrinologist. He was diagnosed with type 2 diabetes mellitus de novo, arterial hypertension, type IIb hyperlipoproteinemia and a state following an insult of the occipital part of right hemisphere.

Ophthalmic examination revealed that his right eye visual acuity (VA) was 0.2 and his left eye VA was 0.7 . Intraocular pressure was normal. Relative afferent pupillary defect was observed in the right eye. Pupillary reaction was normal in the left eye. The fundus features of both eyes and fluorescein angiography of the left eye are shown in figure 1 .
Endocrinological evaluation demonstrated obesity and body mass index (BMI) of $36.2 \mathrm{~kg} / \mathrm{m}^{2}$. Serum analyses showed elevated glucose and $\mathrm{HbA} 1 \mathrm{c}(171 \mathrm{mg} / \mathrm{dl} ; 11.5 \%$ respectively). Serum lipid levels including cholesterol, LDL and triglycerides were within normal values but HDL was reduced $(36 \mathrm{mg} / \mathrm{dl})$. Inflammatory markers were positive. C-reactive protein was $11.2 \mathrm{mg} / \mathrm{l}$. Microalbuminuria was also observed: $64.5 \mathrm{mg} / \mathrm{l}$.

A cardiological examination revealed that patient had no symptoms of cardiac ischemic disease. Values for arterial blood pressure in ambulatory conditions and at home were equivalent to first degree hypertension with a dominant raise observed in diastolic pressure $(140 / 100 \mathrm{mmHg})$. The results of objective examination and electrocardiogram were normal. Echocardiogram showed an enlargement of the left atrium $(5 \mathrm{~cm})$, an initial stage of left ventricular hypertrophy (LV mass $282.2 \mathrm{~g}$, LV mass/BSA $125 \mathrm{~g} / \mathrm{m}^{2}$ ) and signs of diastolic dysfunction of left ventricle (E/A $0.8 / 1.27 \mathrm{~m} / \mathrm{s}$ ). A color Doppler scan of carotid arteries showed fibrous plaque on bifurcation of the left carotid artery with $20 \%$ maximum stenosis. The patient followed the recommended endocrinological therapy for six months and his serum analysis improved significantly: glucose, $\mathrm{HbA} 1 \mathrm{c}$ and serum lipids were normal. He was on corticosteroid treatment for 3 weeks. His VA improved: right eye 0.5 and left 1.0 with correction. Fundus clinical features improved as well.

\section{Case 2}

A 50-year-old female was examined at the Medical Retina Department in November 2005 because of deterioration of vision of her left eye. Five years before she had been diagnosed with type 2 diabetes, dyslipidemia and was receiving treatment for hypertension. An ophthalmic examination revealed that her right eye VA was 1.0 and her left eye VA gradually decreased in two weeks from 0.9 to 0.05 . Intraocular pressure was normal in both eyes.

She was referred to an endocrinologist for further investigation and treatment. BMI was $26.5 \mathrm{~kg} / \mathrm{m}^{2}$ and waist circumference $95 \mathrm{~cm}$. Serum analyses revealed elevated glucose and $\mathrm{HbA} 1 \mathrm{c}(122 \mathrm{mg} / \mathrm{dl}$ and $8.5 \%$ respectively). Serum lipids were increased: cholesterol $(410 \mathrm{mg} / \mathrm{dl})$ and triglycerides $(870 \mathrm{mg} / \mathrm{dl})$. Proinflammatory markers were negative. A cardiological examination showed no symptoms of myocardial ischemia. The values for arterial blood pressure were equivalent to HTA of second degree $(160 / 100 \mathrm{mmHg})$. Results of objective examination were normal. An ECG showed sinus rhythm with an incomplete block of right bundle branch. Echocardiography showed enlargement of the left atrium (4.6 $\mathrm{cm}$ ) and signs of diastolic dysfunction of the left ventricle (E/A 0.6/1.0 m/s). A color Doppler scan of carotid arteries showed calcified plaque on bifurcation of right carotid artery with $25 \%$ maximal stenosis. The patient was on low doses of corticosteroids for two months. She followed her diet regimen strictly and took regularly medications for diabetes and 

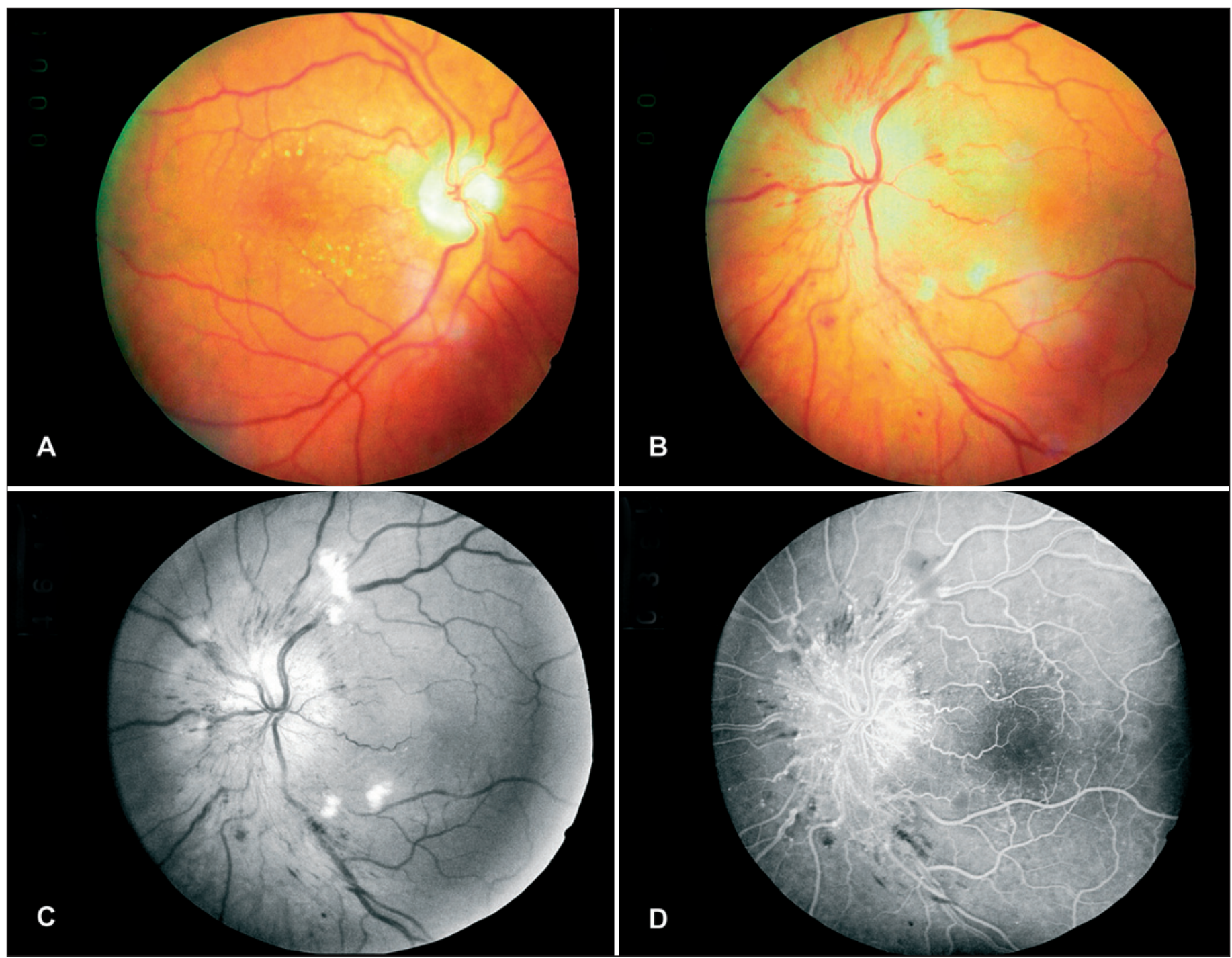

Figure 1 - Fundus photographs of both eyes and red-free as well as fluorescein angiogram of the left eye. A) Fundus of right eye. Optic disc is pale and flat (optic disc atrophy after AION) with changes in retinal vessels and moderate diabetic retinopathy; B) Fundus of left eye. Swollen ischemic optic disc (acute AION), cotton wool exudates, moderate-severe diabetic retinopathy; C) Red free of the left eye shows cotton wool spots and dot hemorrhages, optic nerve with undefined border; D) Fluorescein angiography of left eye, venous phase (36 sec): capillaries of the optic disc are dilated and leak profusely. Stasis of the retinal veins, peripapillary hemorrhages, many microaneurisms around the macula are also observed.

hypertension. Four months later her serum analysis improved: glucose and $\mathrm{HbA1c}$ were normal, total cholesterol was normal, HDL increased to $45 \mathrm{mg} / \mathrm{dl}$, LDL was normal and triglycerides were increased $(326 \mathrm{mg} / \mathrm{dl})$. VA in her left eye improved to 0.7 .

\section{Case 3}

A 55-year-old female was examined at the Medical Retina Department in April 2006, because of deterioration of vision in her right eye. Her past medical history included obesity (BMI $32.4 \mathrm{~kg} / \mathrm{m}^{2}$ ) and hypertension which had lasted more than 25 years (since pregnancy). She has been on treatment since then, but was not examined regularly by a cardiologist. In November 2005 she had a diagnosis of type 2 diabetes (de novo), type IIb hyperlipoproteinemia and polyradiculoneu- ritis. Basic ophthalmological examination revealed that her right VA was 0.1 and left VA was 0.9-1.0. Intraocular pressure was normal in both eyes. The features of fundus and fluorescein angiography of the right eye are shown (Figures 3A and $3 \mathrm{~B}$ ).

A special investigation included endocrinological and cardiological examinations. Her BMI was $32.4 \mathrm{~kg} / \mathrm{m}^{2}$ and her waist circumference $97 \mathrm{~cm}$. Serum analysis showed increased glucose and HbA1c (110 mg/dl and 8.0\%). Proinflammatory markers were negative. High levels of serum cholesterol, LDL and triglycerides were observed $(315 \mathrm{mg} / \mathrm{dl}$, $231 \mathrm{mg} / \mathrm{dl}$ and $168 \mathrm{mg} / \mathrm{dl})$. HDL was normal. Cardiological examination showed no symptoms of ischemic heart disease. There was arterial hypertension of third degree $(190 / 120 \mathrm{mmHg})$. Results of her objective examination were 

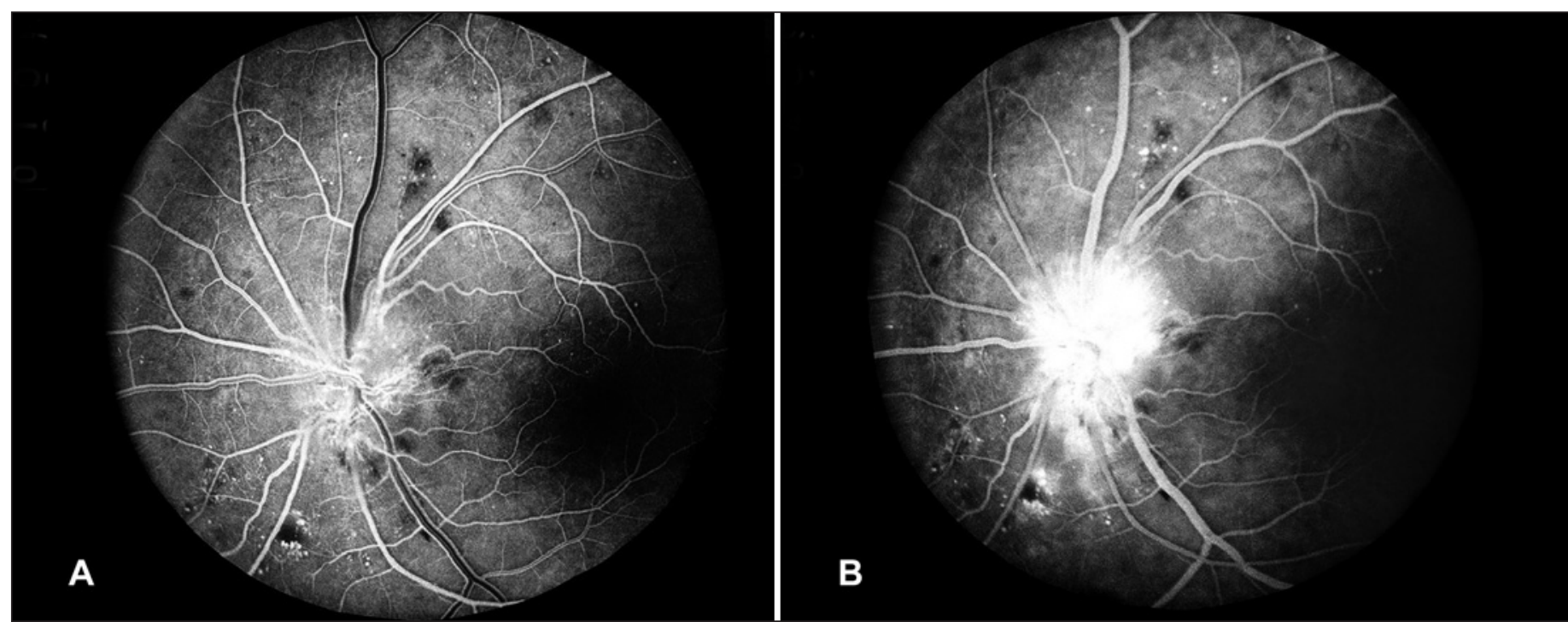

Figure 2 - Fluorescein angiography of the left eye. A) Early phase shows dilatation of prelaminar capillary network of the optic disc and some leakage of dye; B) Late phase shows profuse leakage of dye in the optic disc. Some microaneurisms and dot hemorrhages are also observed.
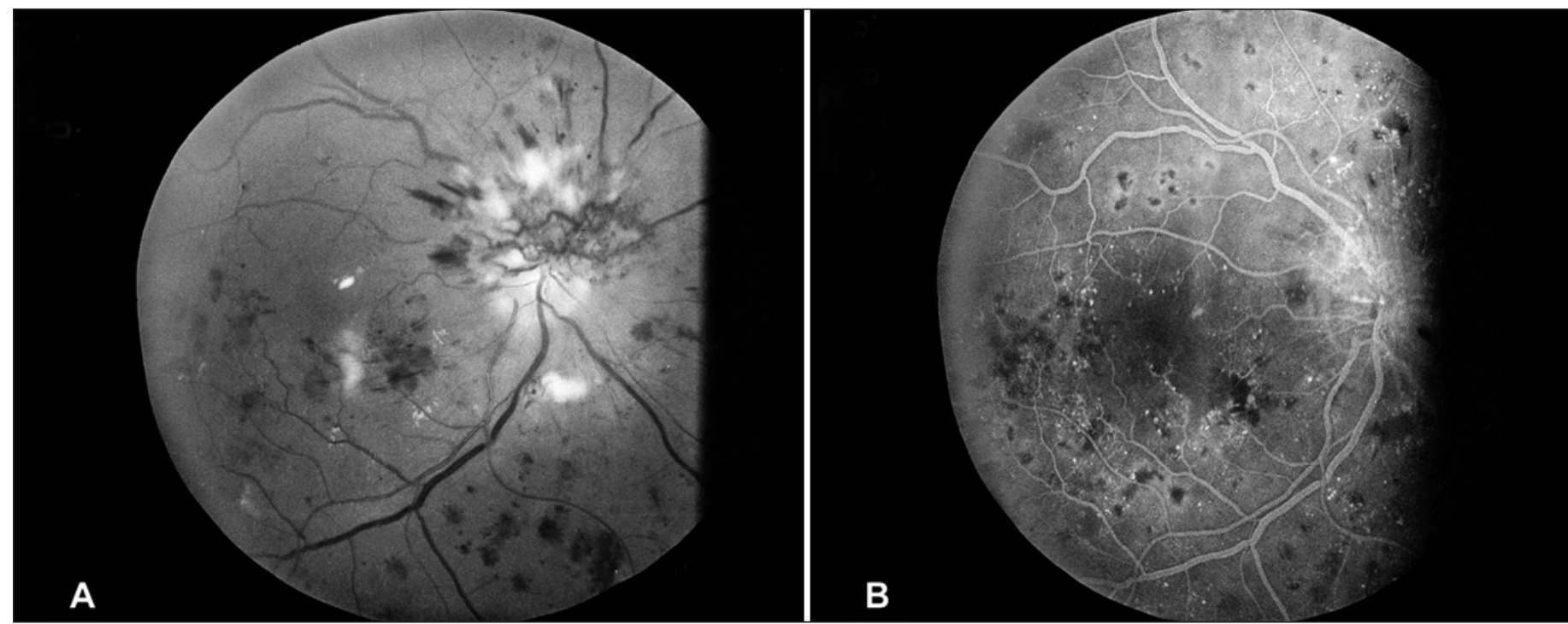

Figure 3 - Red-free and fluorescein angiogram of the right eye. A) Swollen venous ischemic optic disc, splinter-shaped peripapillary haemorrhages (acute AION). Ischemic diabetic maculopathy. Severe non-proliferative diabetic retinopathy was diagnosed; B) Fluorescein angiography shows dilatation of prelaminar capillary network, moderate macular capillary closure, one month after laser treatment.

normal. An ECG showed left ventricular hypertrophy. Echocardiography showed left atrium enlargement $(4.9 \mathrm{~cm})$, left ventricular hypertrophy (LV mass $342 \mathrm{~g}$, LV mass/ BSA $178 \mathrm{~g}$ / $\mathrm{m}^{2}$ ) and signs of diastolic dysfunction. The patient was on strict diet and took medications regularly. After only one month of treatment her serum analyses improved and were within normal limits, except for triglycerides which were still increased (203 $\mathrm{mg} / \mathrm{dl}$ ). Disc edema of the right eye resolved but moderate ischemic diabetic maculopathy remained. Because of pre-proliferative diabetic retinopathy she was submitted to laser photocoagulation treatment. Her best corrected VA improved to 0.7

\section{DISCUSSION}

It is confirmed that factors related to optic disc structure play a role in the patophysiology of NA-AION ${ }^{(7)}$. Patients with MS have increased risk of developing NA-AION because of clustering and synergistic effect of systemic metabolic factors $^{(3)}$. In our patients, we considered the influence of systemic factors related to MS in the pathogenesis of NA-AION. Common features of our three patients were that they were middleaged (mean age 48.6). Their metabolic disorders were diagnosed late and numerous examinations revealed various complications. The visual disorder was the first serious problem that 
alerted our patients to seek medical help and an ophthalmologist was the first physician to examine them.

In our first patient, retinal vascular complications include optic disc atrophy after AION in his right eye and acute AION in left eye within six months. After this second eye complication, he was submitted to a strict treatment for obesity, diabetes, HTA and HLP. VA in the right eye improved partially. Clinical features and VA in the left eye improved as well.

According to the literature, there is no effective and wellestablished therapy for NA-AION, either for visual recovery or for prophylaxis against involvement of the second eye $\mathrm{e}^{(1)}$. The incidence of AION in the second eye is quite high, particularly in young diabetics $(<45 \text { years })^{(1)}$.

Our third patient had obesity and hypertension for more than 25 years, while diabetes and HLP were more recently diagnosed. She followed the prescribed therapeutic regimen and improved her metabolic control within six months. Clinical features and VA in the right eye improved partially.

We believe the clinical findings of this current series are a variety of papillophlebitis which should be treated immediately to try to avoid optic nerve atrophy and irreversibile visual $\operatorname{loss}^{(8)}$.

Patients with MS have an increased risk of $\mathrm{CVD}^{(4-5)}$. In the current series of patients symptoms of coronary disease did not exist. However, structural and functional disturbances of the left ventricle-myocardial hypertrophy and diastolic dysfuntion existed. In the third presented patient these disturbances were most significant and could be explained by longterm irregular control of arterial blood pressure. In all three patients HTA can be considered to be closely related to the development of the diagnosed myocardial hypertrophy and it is also an independent predictor of diastolic dysfunction ${ }^{(9)}$. Along with these factors the development of diastolic dysfunction includes increased BMI and $\mathrm{DM}^{(10)}$. Early recognition of diastolic dysfunction as well as proper treatment can prevent heart failure, coronary heart disease and death.

\section{CONCLUSION}

We observed that a variety of well-known risk factors in MS may be involved in serious eye and cardiological complications. In patients with NA-AION associated with MS a multidisciplinary approach is necessary in order to identify these risk factors. The early diagnosis and treatment of these patients can not only improve visual function but also prevent cardiovascular and cerebrovascular complications.

\section{RESUMO}

Objetivo: A síndrome metabólica indica um grupo comum dos seguintes achados clinicos: obesidade, hipertensão arterial, variações nos níveis de glicemia, dislipidemia, estado proinflamatório e o estado protrombótico. Neuropatia óptica isquêmica anterior é um distúrbio agudo isquêmico da cabeça do nervo óptico que pode levar à perda de visão. Métodos: Consideramos três pacientes com retinopatia diabética não proliferativa moderada e neuropatia óptica isquêmica anterior. Os pacientes foram examinados por endocrinologistas e o diagnóstico de síndrome metabólica foi confirmado. Resultados: $\mathrm{O}$ exame cardiológico revelou que o controle da pressão sangüínea não era adequado e tal anormalidade foi corrigida. A ecocardiografia confirmou os indícios de hipertrofia ventricular esquerda e disfunção diastólica. Estes são os marcadores possiveis da doença cardiovascular pré-clinica. Conclusão: Concluímos que os fatores de risco bem conhecidos, combinados na síndrome metabólica levaram às complicações oculares e às complicações cardiológicas. O diagnóstico anticipado e o tratamento destes pacientes pode não apenas melhorar a função visual mas também impedir as complicações cardiovasculares.

Descritores: Síndrome X metabólica; Neuropatia óptica isquêmica; Doenças cardiovasculares

\section{REFERENCES}

1. Hayreh SS. Ischaemic optic neuropathy. Indian J Ophthalmol. 2000; 48(3): 171-94. Review. Erratum in: Indian J Ophthalmol. 2000;48(4):317.

2. Hayreh SS. Anterior ischaemic optic neuropathy. Differentiation of arteritic from non-arteritic type and its management. Eye. 1990;4(Pt 1):25-41.

3. Nguyen TT, Wong TY. Retinal vascular manifestations of metabolic disorders. Trends Endocrinol Metab. 2006;17(7):262-8.

4. Grundy SM, Hansen B, Smith SC Jr, Cleeman JI, Kahn RA; American Heart Association, National Heart, Lung, and Blood Institute; American Diabetes Association. Clinical management of metabolic syndrome: report of the American Heart Association/National Heart, Lung, and Blood Institute/American Diabetes Association conference on scientific issues related to management. Circulation. 2004;109(4):551-6.

5. Grundy SM, Cleeman JI, Daniels SR, Donato KA, Eckel RH, Franklin BA, Gordon DJ, Krauss RM, Savage PJ, Smith SC Jr, Spertus JA, Costa F; American Heart Association; National Heart, Lung, and Blood Institute. Diagnosis and management of the metabolic syndrome: an American Heart Association/National Heart, Lung, and Blood Institute Scientific Statement. Circulation. 2005;112(17):2736-52. Review. Erratum in: Circulation. 2005; 112(17):e297. Circulation. 2005;112(17):e298.

6. International Diabetes Federation. The IDF consensus worldwide definition of the metabolic syndrome [text on the Internet]. Belgium:IDF; c2006. [cited 2006 June 10]. Available from: http://www.idf.org/webdata/docs/ IDF_Meta_def_final.pdf

7. Monteiro MLR. Anterior ischemic optic neuropathy: a comparison of the optic disc area of patients with the arteritic and non-arteritic forms of the disease and that of normal controls. Arq Bras Oftalmol. 2006;69(6):805-10.

8. Vaphiades MS. The disk edema dilemma. Surv Ophthamol. 2002; 47(2):1838. Comment in: Surv Ophthalmol. 2002;47(6):600-2; author reply 602.

9. Chinali M, Devereux RB, Howard BV, Roman MJ, Bella JN, Liu JE, et al. Comparison of cardiac structure and function in American Indians with and without the metabolic syndrome (the Strong Heart Study). Am J Cardiol. 2004;93(1):40-4.

10. de Simone G. State of the heart in the metabolic syndrome. Nutr Metab Cardiovasc Dis. 2005;15(4):239-41. 